\title{
The effects of ingested petroleum on oviposition and some aspects of reproduction in experimental colonies of mallard ducks (Anas platyrhynchos)
}

\author{
W. N. Holmes, K. P. Cavanaugh and J. Cronshaw \\ Department of Biological Sciences, University of California, Santa Barbara, \\ California 93106, U.S.A.
}

\begin{abstract}
Summary. Compared to unmated mallard ducks fed an uncontaminated diet, unmated birds given food contaminated with $3 \mathrm{ml}$ South Louisiana crude oil per $100 \mathrm{~g}$ dry weight showed an $84 \%$ decline in the daily rate of oviposition, a $33 \%$ decrease in egg-shell thickness and at autopsy more than $82 \%$ of the ovarian mass consisted of atretic follicles. Similar studies on groups of mated females showed that although the addition of $1 \mathrm{ml}$ South Louisiana crude oil $/ 100 \mathrm{~g}$ dry food had no effect on the daily rate of oviposition, none of the eggs had been fertilized while a concentration of $3 \mathrm{ml}$ South Louisiana crude oil/100 $\mathrm{g}$ dry food suppressed the daily rate of oviposition significantly. Less than $25 \%$ of these eggs had been fertilized and only $40 \%$ of the fertilized eggs yielded viable ducklings. In both of these groups of mated birds, normal patterns of oviposition, fertilization and hatchability were restored after removal of petroleum from the diet.

The addition of $1 \mathrm{ml}$ Kuwait crude oil/100 $\mathrm{g}$ dry food had no effect on the rate of oviposition, the incidence of fertility or the hatchability of the fertilized eggs. The addition of $3 \mathrm{ml}$ oil $/ 100 \mathrm{~g}$ dry food completely abolished oviposition, but a normal rate of oviposition was restored when the concentration of the crude oil was reduced from 3 to $1 \mathrm{ml} / 100 \mathrm{~g}$ dry food. However, the incidence of fertilization remained low and none of the fertilized eggs gave rise to viable ducklings. Kuwait crude oil had no effect on shell thickness.
\end{abstract}

\section{Introduction}

During the course of a study on the chronic effects of ingested petroleum in mallard ducks we observed that birds being fed contaminated food did not appear to develop sexually as well as birds being fed uncontaminated food. Birds receiving the contaminated food also failed to display the characteristic patterns of courtship behaviour as frequently as did untreated birds.

This observation was not entirely unexpected because others have shown previously that ingested petroleum adversely affects the fecundity of birds (Hartung, 1965; Grau, Roudybush, Dobbs \& Wathen, 1977). These studies, however, were restricted to the acute effects of single doses administered either by stomach tube or contained within gelatin capsules. In contrast, the apparent attenuation of sexual development in our flock of mallard ducks was occurring among birds that had freely consumed petroleum-contaminated food for several months.

We therefore attempted to evaluate some of the gross effects that ingested petroleum might have on reproduction in small standard colonies of mallard ducks maintained in the laboratory.

\section{Materials and Methods}

Fertilized mallard duck eggs were purchased from a commercial breeder (Whistling Wings, Hanover, Illinois, U.S.A.) and incubated in the laboratory at $37.4^{\circ} \mathrm{C}$ and $64 \%$ relative humidity. Following hatching, the ducklings were maintained in brooders for 4 weeks and thereafter they were held in 
rooms at $27^{\circ} \mathrm{C}$ with a short photoperiod of $8 \mathrm{~h}$ light and $16 \mathrm{~h}$ darkness. When 16 weeks old, the ducks were allocated to experimental and control groups: the experimental birds were given food contaminated with crude oil from South Louisiana or Kuwait and the control birds continued to receive uncontaminated food. The Kuwait and South Louisiana crude oils were obtained from analysed stocks reserved for scientific investigations by the American Petroleum Institute, Washington, D.C., U.S.A.; these oils have been designated A.P.I. reference oils I and II respectively (Table 1). Fresh samples of food containing concentrations of $1 \mathrm{ml}$ and $3 \mathrm{ml}$ crude oil per $100 \mathrm{~g}$ dry weight were prepared each morning. Contaminated and uncontaminated food remaining from the previous day was replaced with fresh food at $08: 00 \mathrm{~h}$ and all groups of birds were allowed to feed ad libitum.

Table 1. Some of the chemical constituents in the crude oil samples used to contaminate the food of the experimental mallard ducks

\begin{tabular}{|c|c|c|c|c|c|c|}
\hline & \multirow[b]{2}{*}{$\begin{array}{l}\text { Asphaltines } \\
\text { (\% weight) }\end{array}$} & \multirow[b]{2}{*}{$\begin{array}{l}\text { Sulphur } \\
\text { (\% weight) }\end{array}$} & \multirow[b]{2}{*}{$\begin{array}{l}\text { Nitrogen } \\
\text { (\% weight) }\end{array}$} & \multicolumn{3}{|c|}{$\begin{array}{l}\text { Hydrocarbon composition } \\
\text { ( } \% \text { total hydrocarbon) }\end{array}$} \\
\hline & & & & Paraffins & $\begin{array}{l}\text { Naphthenes } \\
\text { (cycloparaffins) }\end{array}$ & Aromatics \\
\hline South Louisiana oil & 0 & 0.25 & 0.07 & $36 \cdot 6$ & $44 \cdot 8$ & $18 \cdot 6$ \\
\hline Kuwait oil & 4.5 & $2 \cdot 44$ & $0 \cdot 14$ & $55 \cdot 5$ & 20.2 & $24 \cdot 3$ \\
\hline
\end{tabular}

After maintenance on this feeding regimen for 100 days the birds were placed in colonies of either 6 females or 6 females and 2 males and housed in $5 \times 3 \mathrm{~m}$ runs containing 6 nest boxes and a pool of water $1.5 \mathrm{~m}$ in diameter and $20 \mathrm{~cm}$ deep. On the first day of the experiments (Day 1) the photoperiod was changed to $18 \mathrm{~h}$ light and $6 \mathrm{~h}$ dark and the ensuing patterns of oviposition were examined for unmated (Groups 1 and 2) or mated (Groups 3-8) females. The birds fed an uncontaminated diet for 100 days before the start of the experiment were allocated to Groups 1, 3 and 6.

Unmated females. These received uncontaminated food (Group I) and South Louisiana crude oil, $3 \mathrm{ml} / 100 \mathrm{~g}$ dry food (Group 2), from Days 1 to 50, and were killed on Day 51.

Mated females. These were treated as follows: Group 3 were fed uncontaminated food from Days 1 to 100; Group 4 were fed South Louisiana crude oil, $1 \mathrm{ml} / 100 \mathrm{~g}$ dry food, from Days 1 to 50 and uncontaminated food from Days 51 to 100 ; Group 5 were fed South Louisiana crude oil, $3 \mathrm{ml} / 100 \mathrm{~g}$ dry food, from Days 1 to 50 and uncontaminated food from Days 51 to 100; Group 6 received uncontaminated food from Days 1 to 37 and South Louisiana crude oil, $3 \mathrm{ml} / 100 \mathrm{~g}$ dry food, from Days 38 to 100; Group 7 received Kuwait oil, $1 \mathrm{ml} / 100 \mathrm{~g}$ dry food, from Days 1 to 100 ; and Group 8 were fed Kuwait crude oil at a dose of $3 \mathrm{ml} / 100 \mathrm{~g}$ dry food from Days 1 to 50 and $1 \mathrm{ml} / 100 \mathrm{~g}$ dry food from Days 51 to 100 .

Each morning at 11:00 h eggs were collected from the nesting boxes and numbered. Eggs collected from colonies that included male birds were placed in an incubator (Humidaire, Model 14G, New Madison, Ohio) at $37.4^{\circ} \mathrm{C}$ and $64 \%$ relative humidity. The eggs were sprayed with water twice daily and automatically rotated $90^{\circ}$ every $2 \mathrm{~h}$. On the 7 th day of incubation, and each day thereafter, the eggs were candled. If signs of embryonic development were not identified by the 10 th day of incubation, the eggs were removed from the incubator and were opened; when there was no evidence of early embryonic development, the eggs were considered to have been unfertilized. The criteria described by Hanson (1954) were used to determine whether eggs had been fertilized and to identify the occurrence of prenatal mortality during incubation.

Eggs collected from the colonies of unmated birds and unfertilized eggs from the colonies of mated females were opened and the shell thickness was measured with a double-convex micrometer calliper (Ames, Model 25M, Waltham, Massachusetts) at three points around the equator of the egg.

The unmated birds were killed with an intravenous dose of pentobarbitone sodium and the ovaries and reproductive tracts were removed, weighed and fixed in neutral buffered formalin. The hierarchy. 
of follicular sizes occurring in each ovary was determined by removing the follicles and classifying them according to size and appearance.

All mean values were expressed \pm standard error of the mean (s.e.m.) and were compared by the two-tailed Student's $t$ test.

\section{Results}

The plumage of the birds given petroleum-contaminated food did not become fouled and, throughout the experiments, none of the birds showed any overt symptoms of distress. During the 100-day period that preceded the division into the experimental groups, the mean daily food consumption of the birds given petroleum-contaminated food was never less than that of the birds given uncontaminated food; indeed, the birds given food contaminated with South Louisiana crude oil frequently ate significantly more than the birds given uncontaminated food (Table 2). Although the daily food intake was not monitored after the breeding colonies had been established, the pattern of food consumption by each group, as indicated by body weight changes (Table 2) showed no apparent change.

The chronic consumption of petroleum was not accompanied by any significant loss in body weight and at the beginning of the breeding experiment the mean body weights of each group did not differ significantly from those of the control birds that had always received uncontaminated food (Table 2).

Eggs collected from the nest boxes could not be assigned to particular females and therefore all rates of oviposition relate to the number of eggs collected each day from the standard colonies of 6 female birds.

\section{Oviposition among unmated females}

As shown in Text-fig. 1, the first eggs were laid by Group 1 females on Day 13 . During the next 38 days, these 6 females laid 109 eggs and the mean rate of oviposition was $2 \cdot 87 \pm 0 \cdot 19$ eggs/day. In contrast, Group 2 females did not start to lay until Day 20; they laid only 17 eggs during the next 31 days and showed a highly variable mean daily rate of oviposition of only $0.55 \pm 0.09$ eggs/day.

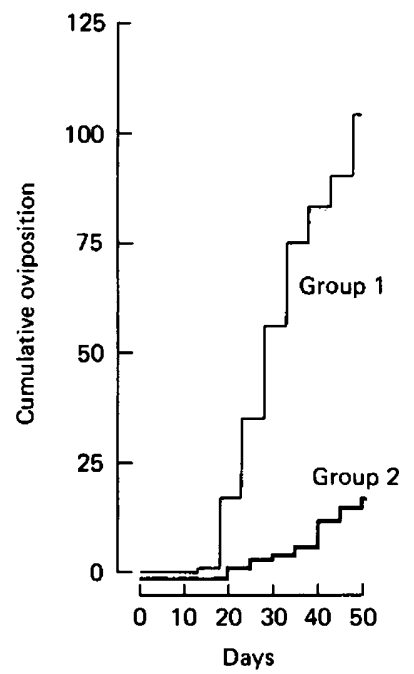

Text-fig. 1. The rates of oviposition of the unmated mallard ducks in Groups 1 (uncontaminated food) and 2 (food contaminated with $3 \mathrm{ml}$ South Louisiana crude oil $/ 100 \mathrm{~g}$ dry weight). Each group consisted of 6 females and the cumulative oviposition record is plotted at consecutive 5-day intervals.

\section{Oviposition of mated females}

The fertilization rate and hatchability of the eggs laid by Group 3 females was consistent (Table 3) although the daily rate of oviposition varied (Text-fig. 2a) because some of the females began to brood. 
$W . N$. Holmes et al.

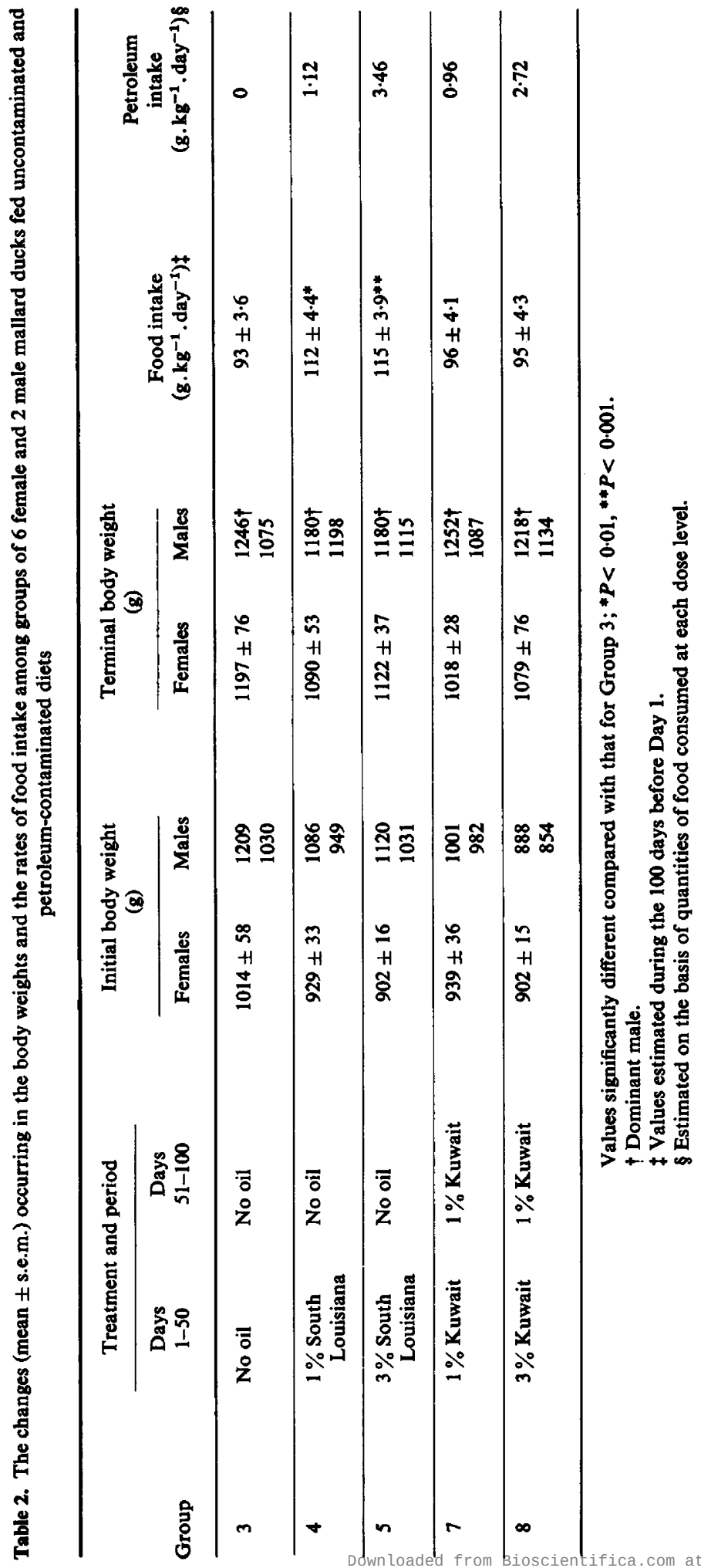








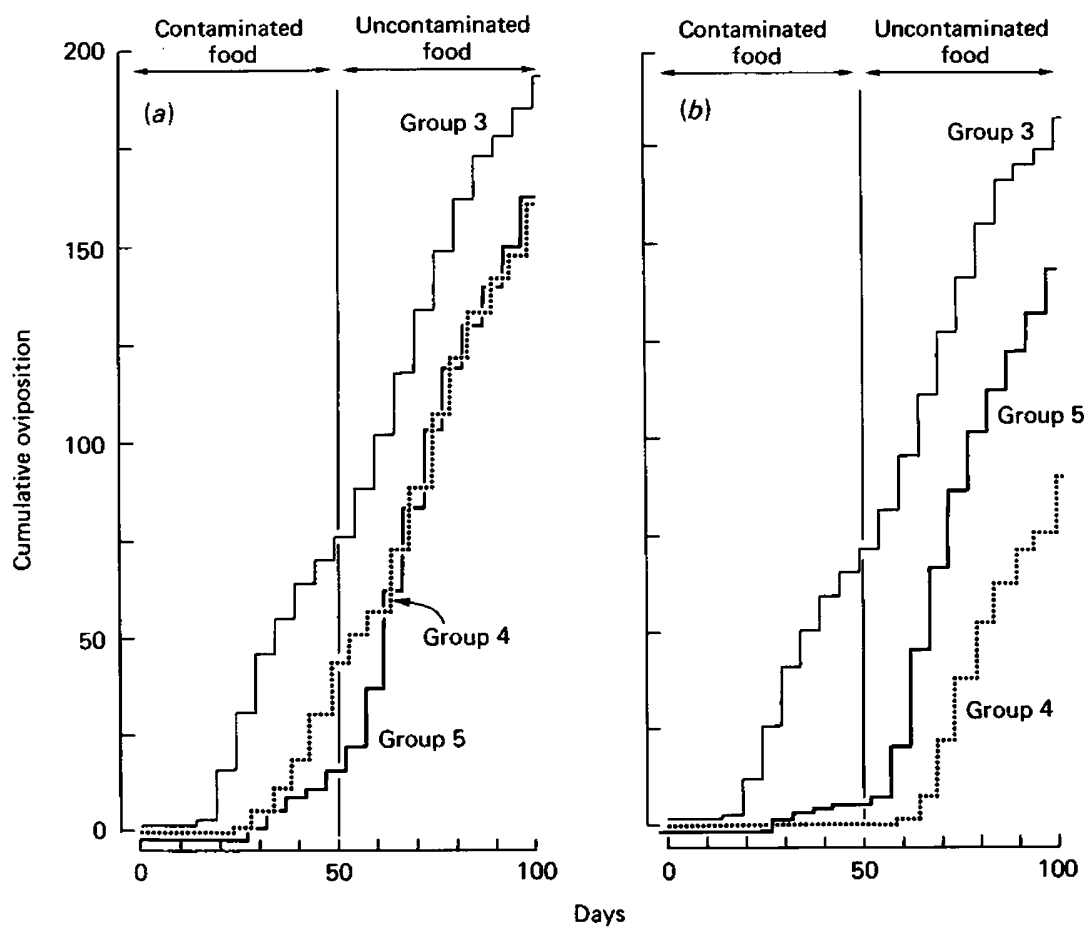

Text-fig. 2. The rates of oviposition of (a) all eggs (fertilized and unfertilized) and (b) fertilized eggs by mallard ducks kept in groups of 6 females and 2 males and fed different diets. Group $3(-)$ received uncontaminated food from Days 1-100; Group $4(\cdots)$ received $1 \%$ South Louisiana crude oil from Days 1 to 50 and then uncontaminated food; Group 5 (- received $3 \%$ crude oil from Days 1 to 50 and then uncontaminated food. The cumulative oviposition record is plotted at consecutive 5-day intervals.

Effects of South Louisianna crude oil. The birds in Groups 4 and 5 were slow to start laying; those in Group 4 had laid only unfertilized eggs by Day 50 and fertilization and hatching of the eggs of Group 5 females were reduced (Table 3; Text-fig. 2a). Within 5 days of removing petroleum from the food, the mean daily rates of oviposition of birds in Groups 4 and 5 increased and the hatchability of the fertilized eggs was restored to normal (Table 3; Text-fig. 2b).

The results for birds in Group 6areshown in Text-fig. 3. A normal pattern of oviposition was established while the birds were eating uncontaminated food; they began to lay on Day 14 and during the next 22 days they laid 81 eggs of which $78(96 \%)$ had been fertilized and 60 of them yielded live ducklings ( $77 \%$ hatchability). When crude oil (3\%) was added to the diet on Day 37 , a reduced rate of oviposition was not apparent until 17 days later (Day 54). Between Days 54 and 100 the birds laid only 25 eggs; 20 of these had been fertilized but only 3 yielded viable ducklings. These results contrasted markedly with those obtained when petroleum was removed from the diet (see Table 3 and Text-fig. 2).

Effects of Kuwait crude oil. The birds in Groups 7 started to lay on the same day as those in Group 3 but laid more eggs until Day 50 (Table 3; Text-fig. 4). However, the incidence of fertilization (73\% versus $92 \%$ ) and the hatchability of the eggs were lower than those of the eggs laid by the birds in Group 3 (Table 3). When the birds were given the same diet for a further 50-day period, the rates of oviposition declined significantly $(P<0.001)$; although the proportion of fertilized eggs laid increased $(89 \%$ versus $73 \%$ for Days $14-50$ ), their hatchability remained unchanged (Table 3 ). In Group 8 there was complete inhibition of oviposition during the first 50 days of the experiment, but when the petroleum concentration was reduced the birds started to lay after 7 days and the total oviposition rate was subsequently normal (Text-fig. 4). However, the proportion of fertilized eggs was extremely low and none of the eggs yielded viable ducklings (Table 3) 




Text-fig. 3. The rates of oviposition of all eggs and fertilized eggs by 6 mallard females kept with 2 males and fed uncontaminated food for 35 days and diet contaminated with $3 \mathrm{ml}$ South Louisiana crude oil/100 g dry food thereafter. The cumulative oviposition record is plotted at consecutive 5-day intervals.

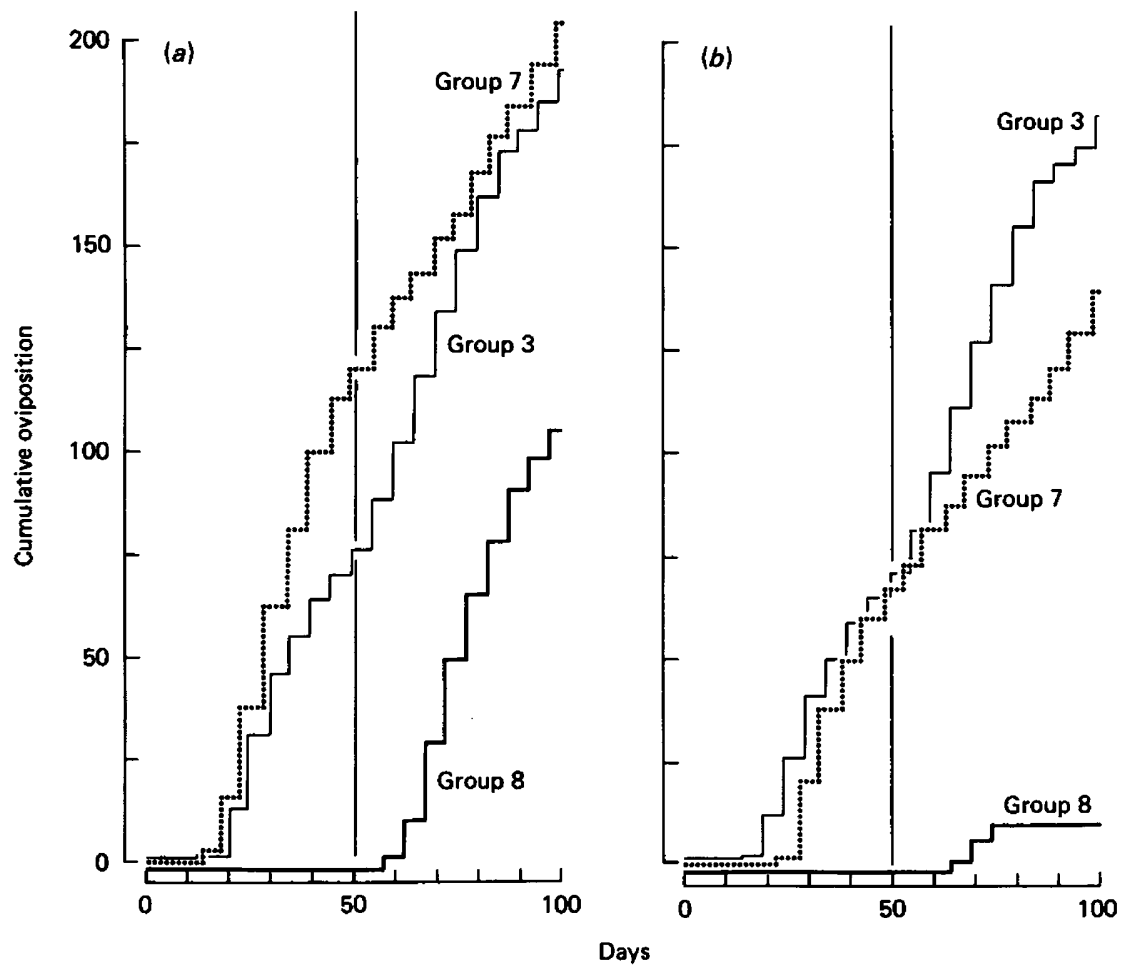

Text-fig. 4. The rates of oviposition of (a) all eggs (fertilized and unfertilized) and (b) fertilized eggs by mallard ducks kept in groups of 6 females and 2 males and fed different diets. Group $3(\longrightarrow$ received uncontaminated food from Days 1 to 100 ; Group $7(\cdots \cdot)$ received $1 \%$ Kuwait crude oil from Days 1 to 100; Group 8 (-) received 3\% Kuwait crude oil from Days 1 to 50 and $1 \%$ oil from Days 51 to 100 . The cumulative oviposition record is plotted at consecutive 5-day intervals. 


\section{Eggshell thickness}

The shells of the eggs laid by unmated and mated females given food containing South Louisiana crude oil (Groups 2, 4 and 5) were significantly thinner than those laid during the same interval by the control birds in Groups 1, 3 and 6 (Table 4). When birds of Groups 4 and 5 were fed the uncontaminated food the shell became thicker and similar to that of unfertilized eggs in Group 3 birds between Days 51 and 100 (Table 4). The birds fed the uncontaminated food tended to lay eggs that had progressively thinner and thinner shells throughout the 100-day experimental period, i.e. the mean shell thickness of eggs laid between Days 51 and 100 was about $9 \%$ less than that of eggs laid between Days 1 and 50 (Table 4). Furthermore, when birds began to lay eggs with thicker shells after removal of South Louisiana crude oil from the food (Days 51-100), the higher mean shell thickness corresponded to the contemporaneous mean thickness recorded for eggs laid by the control birds during the same period.

Table 4. The changes (mean \pm s.e.m., no. of eggs in parentheses) in shell thickness of unfertilized eggs laid by colonies of mated ( 6 females, 2 males) and unmated ( 6 females) mallard ducks fed uncontaminated food and food contaminated with different amounts of South Louisiana or Kuwait oil

\begin{tabular}{|c|c|c|c|c|c|c|}
\hline Group & Treatment & $\begin{array}{c}\text { Duration } \\
\text { (days) }\end{array}$ & $\begin{array}{c}\text { Shell } \\
\text { thickness } \\
(\mu \mathrm{m})\end{array}$ & Treatment & $\begin{array}{c}\text { Duration } \\
\text { (days) }\end{array}$ & $\begin{array}{c}\text { Shell } \\
\text { thickness } \\
(\mu \mathrm{m})\end{array}$ \\
\hline 1 & $\begin{array}{l}\text { No oil } \\
\quad \text { (unmated) }\end{array}$ & $1-50$ & $329 \pm 3$ & - & - & - \\
\hline 2 & $\begin{array}{l}3 \% \text { South } \\
\text { Louisiana } \\
\text { (unmated) }\end{array}$ & $1-50$ & $* * * 222 \pm 9(12)$ & - & - & - \\
\hline 3 & $\begin{array}{l}\text { No oil } \\
\text { (mated) }\end{array}$ & $1-50$ & $363 \pm 9(6)$ & No oil & $51-100$ & $\dagger 332 \pm 10(5)$ \\
\hline 4 & $\begin{array}{l}1 \% \text { South } \\
\text { Louisiana } \\
\text { (mated) }\end{array}$ & $1-50$ & $* * * 294 \pm 9(29)$ & No oil & $51-100$ & $\dagger \dagger 329 \pm 5(23)$ \\
\hline 5 & $\begin{array}{l}3 \% \text { South } \\
\text { Louisiana } \\
\text { (mated) }\end{array}$ & $1-50$ & $* * * 236 \pm 19(8)$ & No oil & $51-100$ & $\dagger \nmid 330 \pm 15(4)$ \\
\hline 6 & $\begin{array}{l}\text { No oil } \\
\text { (mated) }\end{array}$ & $1-36$ & $343 \pm 5(3)$ & $\begin{array}{l}3 \% \text { South } \\
\text { Louisiana }\end{array}$ & $37-100$ & $t \dagger \dagger 258 \pm 13(5)$ \\
\hline 7 & $\begin{array}{c}1 \% \text { Kuwait } \\
\text { (mated) }\end{array}$ & $1-50$ & $351 \pm 4(14)$ & $1 \%$ Kuwait & $51-100$ & $\dagger 338 \pm 3(5)$ \\
\hline 8 & $\begin{array}{l}3 \% \text { Kuwait } \\
\text { (mated) }\end{array}$ & $1-50$ & No oviposition & $1 \%$ Kuwait & $51-100$ & $334 \pm 4(37)$ \\
\hline
\end{tabular}

Values significantly different from that of the respective control eggs (Groups 1 and 3 ); ***P<0.001.

Values significantly different from the corresponding value in the preceding period; $+P<0.05,++P<0.01$; $+t+P<0.001$.

In birds of Group 6, the mean shell thickness of the unfertilized eggs was significantly lower during the period of diminished oviposition (Days 54-100) than previously (Days 1-36) (Table 4).

The addition of Kuwait crude oil to the diet (Groups 7 and 8) had no significant effect on the mean shell thickness of unfertilized eggs. During the 100-day experimental period a significant decline in mean shell thickness occurred and this decline corresponded to that observed in the eggs laid by the control Group 3 birds (Table 4).

\section{Effects on the oviduct and ovary}

With the exception of one bird (No. 16) that did not appear to have laid for at least 1 week before autopsy, the oviducts were well developed in the Group 1 birds. In contrast, the oviducts taken from 5 of the 6 birds in Group 2 were small and anaemic (Table 5 ). Bird 23 had ovulated shortly before: 
종

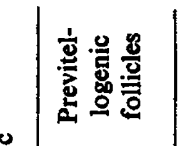

oritionn



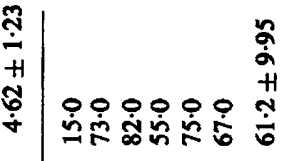

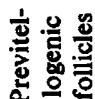

奈

西

$00 \stackrel{+}{\circ} 000 \stackrel{2}{2}$

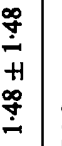

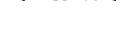

은

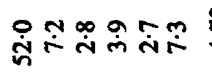

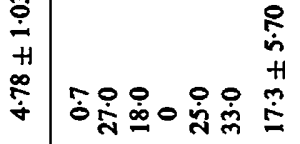

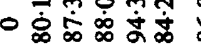

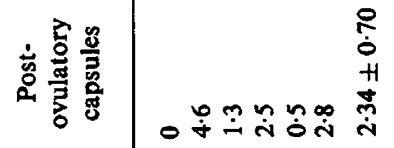

0000000

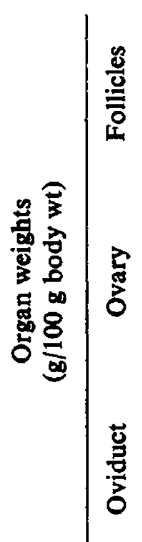



总

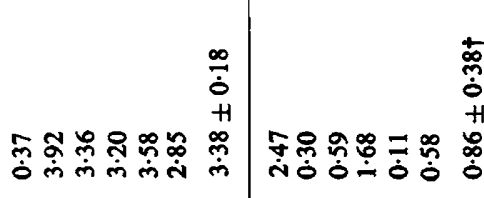

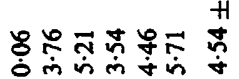

궁

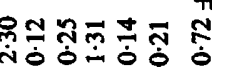

홈

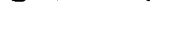

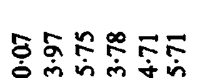



mo

0000000

خें

壱 V

.

至

농.

동용



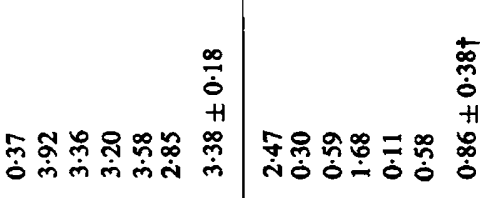

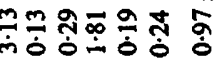

$\stackrel{+}{\circ}$

㐘密

궁

으 훈

운.

Z

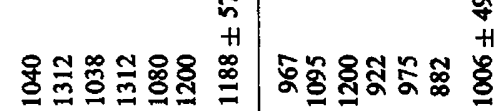

宫

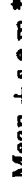



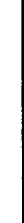

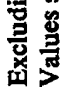


autopsy and the oviduct was large and well vascularized. Vitellogenesis was occurring and yolk was present in the peritoneal cavities of Birds 14, 18, 25 and 35 although the livers did not have the characteristic yellow-brown coloration found in the control birds.

The relative size of the ovary and the proportion of follicles at various stages of development and atresia were quite different in the two groups of birds (Table 5, Plate 1). For purposes of comparison, five stages of follicular development and atresia were identified. The proportion of non-atretic follicles was $87 \pm 6.4 \%$ in the Group 1 birds and $17 \pm 5.2 \%$ in the Group 2 birds. Most of the follicular mass in Group 1 females consisted of non-atretic vitelline follicles (Table 5). The ovaries from birds given the petroleum-contaminated food were small when compared to those from the control birds and the absence of non-atretic vitelline follicles, even in the single bird (No. 23) that had laid just before autopsy, was apparent (Table 5). Furthermore, although these ovaries contained large numbers of non-atretic previtelline follicles, the numbers that had already become atretic suggested that many of the non-atretic forms would also ultimately undergo atresia (Table 5).

\section{Discussion}

There is little doubt among ornithologists that the persistent spillage of petroleum during the past 50 years has been a major factor contributing to the decline of many colonies of seabirds (Bourne, 1968; Parslow, 1976a, b; Holmes \& Cronshaw, 1977). The present study has shown that the ingestion of petroleum clearly influences some aspects of reproduction in the female mallard duck and, although the evidence is circumstantial, it may also affect sexual activity in males. It is improbable that these effects would seriously reduce the size of most wild mallard duck populations but similar effects among colonies of some other species could have a profound influence on their population size.

The overall biological implication of these studies, therefore, may be much easier to evaluate than the precise effects that petroleum hydrocarbons may have on differentiating reproductive tissues. For example, in species such as the guillemot, for which annual recruitment within colonies may normally be as low as $\mathbf{0 \cdot 2}$ individuals per breeding pair, even a slight impairment of reproductive capacity would seriously endanger their survival (Upenskii, 1956; Tuck, 1961 ; Southern, Carrick \& Potter, 1965). In other species, only a small delay in the onset of breeding may make it impossible for the reproductive cycle to be completed before seasonal climatic change causes severe mortality among the fledglings or the birds migrate from the breeding grounds.

The present data do not identify the nature of any interaction that may occur between a petroleum contaminant in the food and any endocrine mechanism associated with reproduction. Some of the differences between the effects of the South Louisiana and Kuwait crude oils, however, seem to suggest that each oil may affect different phases of reproductive development. For example, in addition to impairing normal development of the ovary, the ingestion of South Louisiana crude oil may have caused an impairment of one or more other processes such as spermatogenesis in the male, pre-nuptial behaviour in both sexes and the storage and viability of spermatozoa in the female because fertilization was affected. A low dose of Kuwait crude oil had no effect on either oviposition or the incidence

\section{EXPLANATION OF PLATE 1}

Ovaries from unmated mallard ducks fed on uncontaminated diet (Fig. 1) and a diet contaminated with $3 \mathrm{ml}$ South Louisiana crude oil/100 $\mathrm{g}$ dry weight (Fig. 2). The inserts show these two sets of ovaries at the same magnification $(\times 0.35)$.

Fig. 1. Normal ovaries from birds in Group 1 (uncontaminated food) that were laying at the time of autopsy. These ovaries are characterized by the presence of the capsules (cap) that remain after ovulation. The bulk of the ovary is composed of large vitelline follicles ( $v f$ ) with a distinct network of blood vessels. Numerous small immature previtelline follicles (pvf), a few of which seem to have undergone atresia (apvf), are also present. $\times 0.75$.

Fig. 2. Abnormal ovaries from unmated birds in Group 2 (petroleum-contaminated diet for 50 days). The insert shows clearly that these ovaries were much smaller than normal. Two of the ovaries contain large masses of vitelline follicles that have undergone atresia during the late stages of their development (avf). No empty capsules are present and the remainder of each of these ovaries and the whole of the third ovary consist of small previtelline follicles, most of which appear to be atretic (apvif) $\times \mathbf{1} \cdot \mathbf{1 2}$ : Com at $04 / 26 / 2023$ 11:40:14AM 

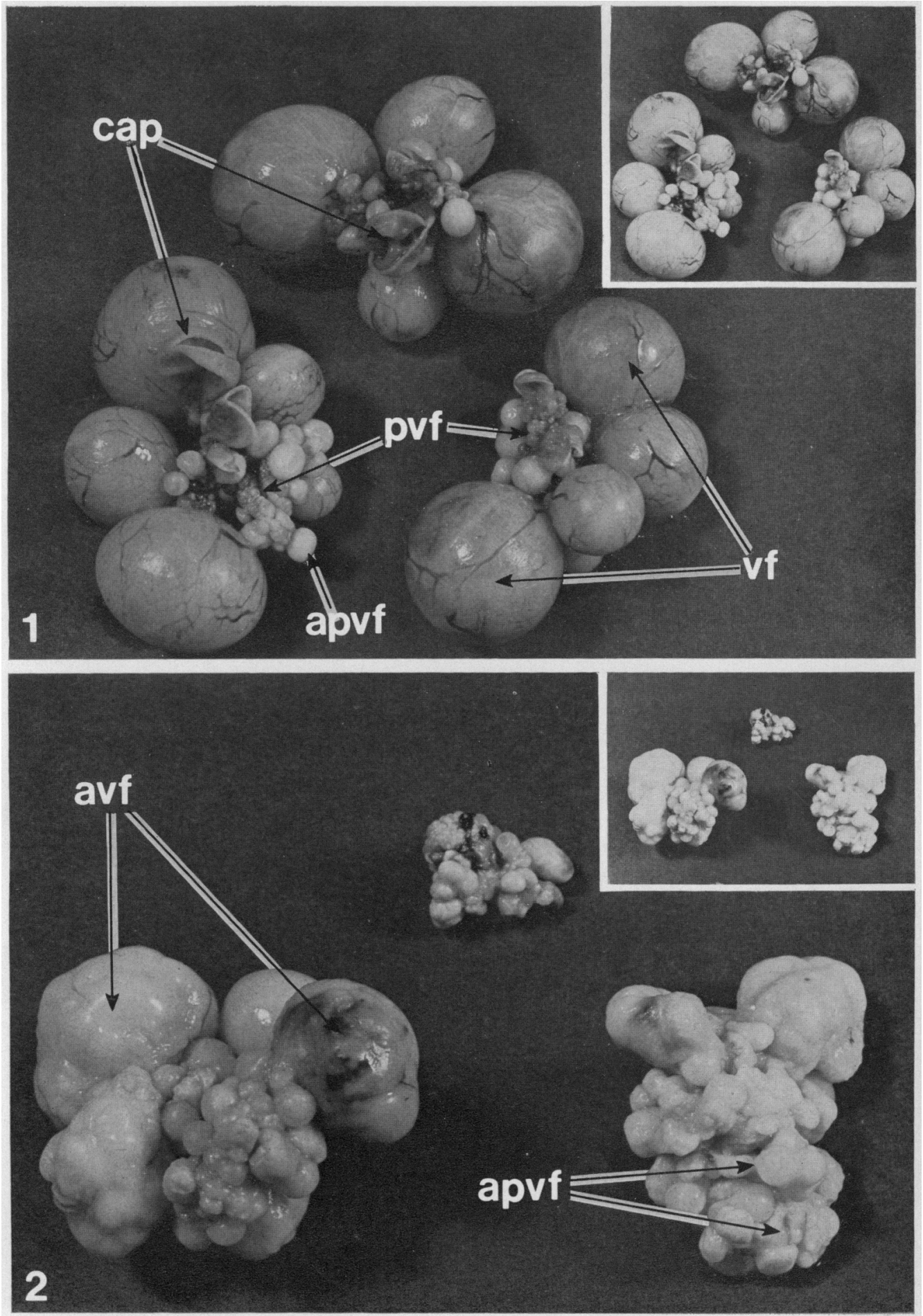
of fertilization but the high dose seemed to impair vitellogenesis and subsequent differentiation of the ovarian follicles. The South Louisiana crude oil and the Kuwait crude oil also had distinctly different effects on shell thickness.

The different effects of the two oils may be due to their different chemical compositions (Table 1). Whatever the nature of their inhibitory effects might be, however, an hypothesis proposing a systemic effect must be based on the belief that the active principle in the petroleum is absorbed from the gut. There is at present no direct evidence to support this belief. Studies on other hydrocarbons have shown that when they occur as environmental pollutants, only very small quantities seem to enter the tissues (Hardy, Mackie, Whittle \& McIntyre, 1974; Peakall \& Kemp, 1976; Clark \& Peakall, 1977; Varanasi \& Malins, 1977). Although these small amounts may be difficult to identify by conventional analysis, they sometimes have well defined biological effects and these have often been used as presumptive indicators of tissue contamination (see Malins, 1977). One such effect is to induce an increase in hepatic mixed function oxidase activity (Hart \& Fouts, 1963; Hart, Shultice \& Fouts, 1963; Gerboth \& Schwabe, 1964; Ghazel, Koransky, Portig, Vohland \& Klempau, 1964). Experiments on the herring gull (Larus argentatus) have shown that the ingestion of petroleum is followed by an increase in hepatic mixed function oxidase activity (Miller, Peakall \& Kinter, 1978) and we have recently confirmed this observation in experiments on the mallard duck (unpublished). These findings have provided the first evidence that when a bird consumes petroleum some of the ingested hydrocarbons may be absorbed from the gut.

Although the precise actions of petroleum hydrocarbons on reproductive tissues within the organism are not known, there certainly seems to be some basis for considering that the birds used in this study had been subjected to chronic non-specific stress. As we have previously shown, birds that have been chronically maintained on food contaminated with any one of a variety of crude oils and petroleum distillation products show adrenal gland hypertrophy, involution of lymphoepithelial tissues and increases in plasma corticosterone concentration (Holmes \& Cronshaw, 1977; Holmes, Cronshaw \& Gorsline, 1978). This stress-induced increase in adrenocortical function may be further compounded by the enhanced metabolism of corticosteroids that is believed to occur after the induction of an increase in hepatic mixed function oxidase activity by the ingested petroleum hydrocarbons (see review, Conney, 1967; Kupfer, Balazs \& Buyske, 1964; Balazs \& Kupfer, 1966a, b; Kupfer \& Partridge, 1970; Kupfer \& Bulger, 1976a, b). In mammals, an impaired ovarian function has frequently been associated with stress-induced increases in adrenocortical activity. The diminished reproduction that we have observed, therefore, may have been a secondary manifestation of prolonged exposure to stress and persistent high levels of corticotrophin secretion (see review, Christian, 1975). Such stressful effects of petroleum would be particularly severe among marine birds. These birds normally sustain high levels of adrenocortical activity to maintain their osmotic balance and the imposition of the additional environmental stresses associated with petroleum ingestion may render them especially sensitive and vulnerable (Crocker, Cronshaw \& Holmes, 1974, 1975; Crocker \& Holmes, 1976; Holmes, 1978).

Other possible explanations for the observed effects of the ingested petroleum hydrocarbons may involve their direct interaction with oestrogen and progestagen receptors in target tissues; such interactions have been observed between some chlorinated hydrocarbons and receptor proteins in both mammalian and avian reproductive tissues (Kupfer, 1976a, b). In birds, there appear to be clear parallels between the effects of some chlorinated hydrocarbons and some of the reported effects of petroleum; in particular, the similarity between the effects of these two groups of compounds on an hormonally regulated mechanism such as shell deposition is striking (see review, Cooke, 1973; Stickel, 1973; Kojala \& Hinton, 1977; Kojala, 1977).

We are grateful to Miss Dana Vaughan who, as an undergraduate employed to tend the flock of mallard ducks, first noticed the difference between the behaviour of the birds maintained on uncontaminated food and those being fed petroleum-contaminated food. We also thank Mrs Ilene Hames who assisted in the preparation of this manuscript. The research was supported in part by a grant to W.N.H. from the Committee on Research, University of California, and funds from the U.S.D.I., Washington, D.C., Contract No. 14-16-0008-2032. 


\section{References}

Balazs, T. \& Kupfer, D. (1966a) Adrenocortical function test: estimation of cortisol production rate in the guinea pig. Toxic. appl. Pharmac. 8, 152-158.

BALAzs, T. \& KUPFER, D. (1966b) Effect of DDT on the metabolism and production rate of cortisol in the guinea pig. Toxic. appl. Pharmac. 9, 40-43.

BOURNE, W.R.P. (1968) Oil pollution and bird populations. In The Biological Effects of Oil Pollution on Littoral Communities, Vol. 2, pp. 99-121. Eds J. D. Carthy \& D. R. Arthur. E. W. Classey, Ltd, Hampton, England.

Christian, J.J. (1975) Hormonal control of population growth. In Hormonal Correlates of Behaviour, Vol. 1, pp. 205-274. Eds B. E. Eleftheriou \& R. L. Sprott. Plenum Press, New York.

Clark, A.L. \& Peakall, D.B. (1977) Organochlorine residues in Eleonora's falcon, Falco eleonorae, its eggs and its prey. Ibis 119, 353-358.

CONNEY, A.H. (1967) Pharmacological implications of microsomal enzyme induction. Pharmac. Rev. 19, 317-366.

Cooke, A.S. (1973) Shell thinning in avian eggs by environmental pollutants. Environ. Poll. 4, 85-152.

Crocker, A.D. \& Holmes, W.N. (1976) Factors affecting intestinal adsorption in ducklings (Anas platyrhynchos). J. Endocr. 71, 88P-89P.

Crocker, A.D., Cronshaw, J. \& Holmes, W.N. (1974) The effect of a crude oil on intestinal adsorption in ducklings (Anas platyrhynchos). Environ. Poll. 7, 165-178.

Crocker, A.D., Cronshaw, J. \& Holmes, W.N. (1975) The effect of several crude oils and some petroleum distillation fractions on intestinal adsorption in ducklings (Anas platyrhynchos). Environ.Physiol. Biochem. 5, 92-106.

Gerboth, G. \& Schwabe, U. (1964) Einflusz von gewebsgespeiehertem DDT auf die Wirkung von Pharmaka. Arch. exp. Path. Pharmak. 246, 469-483.

Ghazal, A., Koransky, W., Portig, J., Vohland, H.W. \& KLempaU, I. (1964) Beschleunigung von Entgiftungsreakitionen durch verschiedene Insecticide. Arch. exp. Path. Pharmak. 249, 1-10.

Grau, C.R., Roudybush, T., Dobbs, J. \& Wathen, J. (1977) Altered yolk structure and reduced hatchability of eggs from birds fed single doses of petroleum oils. Science, N.Y. 195, 779-781.

HANSON, H.C. (1954) Criteria of age of incubated Mallard, Wood Duck and Bob-white Quail eggs. Auk 71, 267-272.

Hardy, R., Mackie, P.R., Whittle, K.J. \& McIntyre, A.D. (1974) Discrimination in the assimilation of $n$-alkanes in fish. Nature, Lond. 252, 577-578.

HART, L.G. \& Fouts, J.R. (1963) Effects of acute and chronic DDT administration on hepatic microsomal drug metabolism in the rat. Proc. Soc. exp. Biol. Med. 114, 388-392.

Hart, L.G., Shultice, R.W. \& Fouts, J.R. (1963) Stimulatory effects of chlordane on hepatic microsomal drug metabolism in the rat. Toxic. appl. Pharmac. 5, 371-386.

HaRTUNG, R. (1965) Some effects of oiling on reproduction of ducks. J. Wildl. Mgmt 29, 872-874.
Holmes, W.N. (1978) Hormonal adaptation in aquatic birds. In Environmental Endocrinology, pp. 230-239. Eds D. S. Farner \& I. Assenmacher. Springer-Verlag, Heidelberg.

Holmes, W.N. \& Cronshaw, J. (1977) Biological effects of petroleum on marine birds. In Effects of Petroleum on Arctic and Subarctic Marine Environments and Organisms, Vol. II, Biological Effects, Ch. 7, pp. 359. 398. Ed. D. C. Malins. Academic Press, New York.

holmes, W.N., Cronshaw, J. \& Gorsline, J. (1978) Some effects of ingested petroleum on seawateradapted ducks (Anas platyrhynchos). Environ. Sci. 17, 177-191.

Kojala, G.J. (1977) The effects of DDT, DDE and their sulfonated derivatives on eggshell formation in the mallard duck. Bull. Environ. Contam. Toxicol. 17, 697-701.

Kojala, G.J. \& Hinton, D.E. (1977) In vitro inhibition of microsomal calcium Atpase [sic] from eggshell gland of mallard duck. Bull. Environ. Contam. Toxicol. 17, 591-594.

KUPFER, D. \& BULGER, W.H. (1976a) Interactions of chlorinated hydrocarbons with steroid hormones. Fedn Proc. Fedn Am. Socs exp. Biol. 35, 2603-2608.

Kupfer, D. \& Bulger, W.H. (1976b) Studies on the mechanism of estrogenic actions of $o, p$ 'DDT: interactions with the estrogen receptor. Pesticide Biochem. Physiol. 6, 561-570.

Kupfer, D. \& Partridge, R. (1970) $6 \beta$ hydroxylation of triamcinolone acetonide by a hepatic enzyme system. The effect of phenobarbital and 1-benzyl-2-thio-5,6dihydrouracil. Archs Biochem. Biophys. 140, 23-28.

Kupfer, D., Balazs, T. \& Buyske, D.A. (1964) Stimulation by $0, p^{\prime}-D D D$ of cortisol metabolism in the guinea pig. Life Sciences 3, 959-964.

Malins, D.C. (Ed.) (1977) Effects of Petroleum on Arctic and Subarctic Marine Environments and Organisms, Vol. II, Biological Effects. Academic Press, New York.

Miller, D.S., Peakall, D.B. \& Kinter, W.B. (1978) Ingestion of crude oil: sublethal effects in herring gull chicks. Science, N. Y. 199, 315-317.

Parslow, J.L.F. (1976a) A census of auks. Br. Trust Ornithol. News 23, 8-9.

Parslow, J.L.F. (1976b) Changes in status among breeding birds in Britain and Ireland. Br. Birds 60 , 2-47, 97-122, 177-202.

Peakall, D.B. \& KemP, A.C. (1976) Organochlorine residue levels in herons and raptors in the Transvaal. Ostrich 47, 139-141.

Southern, H.N., CARRICK, R. \& PotTer, W.G. (1965) The natural history of a population of Guillemots (Uria aalge Pont.). J. Anim. Ecol. 34, 649-665.

Stickel, L.F. (1973) Environmental Contamination by Pesticides. Plenum Press, New York-London.

Tuck, L.M. (1961) The Murres: their Distribution, Populations and Biology, a Study of the Genus Uria. Canadian Wildlife Service, Ottawa.

UPENSKII, S.M. (1956) Bird Bazaars of Novaya Zemlya Academy of Sciences. Moscow, USSR. [English translation: Can. Wildlife Serv., Transl. Russ. Game Report No. 4.] 
Varanast, U. \& Malins, D.C. (1977) Metabolism of petroleum hydrocarbons: Accumulation and biotransformation in marine orranisms. In Effects of Petroleum on Arctic and Subarctic Marine Enoiron- ments and Organtsms. Vol. II. Biological Effects, Ch. 3, pp. 175-270. Ed. D. C. Malins. Academic Press, New York.

Recelved 20 March 1978 